\title{
The Research on Exoskeletons with Focus on the Locomotion Support
}

\author{
jikun Wang \\ Warsaw University of Technology, Faculty of Mechatronics, Institute of Automatic Control and Robotics, św. Andrzeja Boboli 8, 02-525 Warsaw. \\ Poland
}

\section{Linwei Lyu}

Tianjin University of Technology, National Demonstration Center for Experimental Mechanical and Electrical Engineering Education, Tianjin Key laboratory for Advanced Mechatronic System Design and Intelligent Control, Tianjin 300384, China

\begin{abstract}
This paper summarizes the research on exoskeletons focusing on locomotion support and presenting their general features including the general control approaches. The major fields of exoskeleton applications are focused, namely the military and medical fields. The results of our research on muscles activation during human walking are shortly described. The current developmental trends are outlined in the conclusions part.
\end{abstract}

Keywords: lower limb exoskeleton, EMG, gait analysis

\section{Introduction}

The concept of an artificial exoskeleton is inspired by biology. Many living creatures possess external skeletons covering their soft bodies, the classic example are insects. Animal exoskeletons are not only introducing the rigidity of the body but make the safe covering of soft organs, moreover through reconfiguration of the rigid segments, the reshaping of the body, that supports the locomotion, is obtained. Interesting example are the worms covered by segmented shell which can take a ball like form for rolling down the inclined surfaces (see Fig.1)

The human exoskeletons we are not yet reached such advanced stage however those devices have quite long research history, and the recent challenges in this field are impressing. The study on human exoskeletons started in $19^{\text {th }}$ century. The first exoskeleton-like devices were invented by Nicholas Yagin [26] (1890). These devices offered for the wearer the faster running and higher jumping ability. The era of modern exoskeletons started in late seventies of $20^{\text {th }}$ century together with the progress in digital control systems and sensing technologies [25].

Exoskeletons are regarded as a wearable robots or a wearable intelligent devices. They can be categorized as a full-body, upper-body and lower-body supporters. The exoskeletons are used in rehabilitation, they prevent of motion system injuries, they increase the power or enhance the human motion abilities. Moreover, they are used as intelligent prosthesis for amputees,

\section{Autor korespondujący:}

likunWang, jikun.wang@pw.edu.pl

\section{Artykuł recenzowany}

nadesłany 13.02.2020 r., przyjęty do druku 28.04.2020 r. they also allow the locomotion of the persons with different motion impairments.

In this paper we focus on human lower limb exoskeletons. However, the representative example of advanced full body exoskeleton is also mentioned. The walking ability is very crucial for normal functioning of the human being and is required for many working activities. The paper is organized as following: first the lower limb exoskeletons for military and medical applications are shortly presented; next the basic features of a human gait together with outline of our research on muscles activation signals are given. The paper is ending with conclusions.
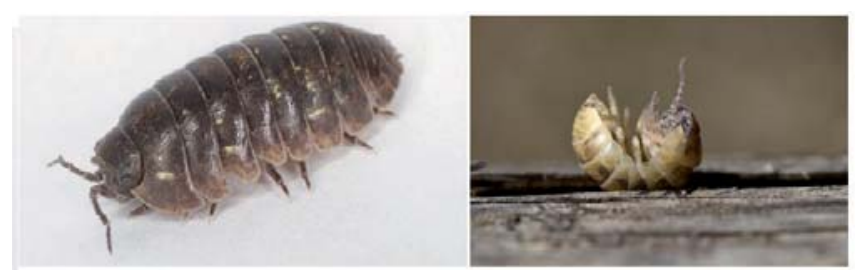

Fig. 1. Armadillidiidae, also known as a pill bug, can reshape its body spherically. Left: pill bug in walking posture [20], photo by Peter O'Connor aka anemoneprojectors on Foter.com/CC BY-SA; right: pill bug taking the ball shape [19], image courtesy of membio at FreeDigitalPhotos.net

Rys. 1. Armadillidiidae, znane również jako kulanka, potrafi zwinąć się w kulkę. Po lewej: kulanka w postawie podczas chodzenia [20], fot. Peter O'Connor znany jako anemoneprojectors na Foter.com/CC BY-SA; po prawej: kulanka przybiera kształt kuli [19], fotografia dzięki uprzejmości membio na FreeDigitalPhotos.net

\section{Exoskeletons for military applications}

The modern exoskeletons augment the force and strength of soldiers carrying the loads to supports the longtime marching. The research on full-body exoskeletons for military applications started more than fifty years ago with the works on HARDI- 
MAN. The HARDIMAN was built within General Electric project named "Human Augmentation Research and Development Investigation" [25]. HARDIMAN was equipped with hydraulic and electric motors. Unfortunately, the HARDIMAN project was not successful, because the actuators were producing violent and uncontrolled motions. In 2001, the Defense Advanced Research Projects Agency (DARPA, USA) started its own research on exoskeletons launching the program "Exoskeletons for Human Performance Augmentation" [16]. It aimed the design of exoskeletons augmentating the user forces. Between others, the Sarcos company was appointed to this project, and in 2006, DARPA successfully accepted the exoskeleton prototype by them. In 2010, Sarcos company delivered XOS exoskeleton. XOS is a full-body exoskeleton that enhances user's strength by hydraulic actuators. XOS allows to carry the armor and other heavy objects [10]. The company progressed farther the exoskeletons development what lead to the very advanced Guardian XO exoskeleton suit for industrial workers, presented recently (2019) [17]. Another example of the DARPA supported designs is the Berkeley Lower Extremity Exoskeleton (BLEEX). The project was ordered in 2000, immediately after launching "Exoskeletons for Human Performance Augmentation".

BLEEX allowed the soldier to carry the heavy loads over the long distances [23]. The force augmenting actuators were increasing the leg joints power and the waist holder allowed to distribute properly the loads carried by soldiers. The example of partial exoskeleton is ONYX, which developed from motorized knee brace. It was the work of Lockheed Martin company financed by U.S. Army Natick Soldier Research, Development and Engineering Center (NSRDEC). Within this project started in 2018, the basic version of ONYX was enhanced to the advanced exoskeleton. ONYX uses artificial intelligence for predicting the joints movement. Another U.S. program called Tactical Light Operator Suit (or TALOS) [14] delivered a "superman" suit which is bulletproofed, weaponized and is strength enhancing. The project was started in 2013 and the advanced prototype was planned for demonstration in 2018, however it seems that the project was not so successful as it was assumed. Besides of some problems the research on exoskeletons for special applications is continuing. The actual developmental trends are focusing on soft, light weighted devices with long-lasting endurance. Their control strategies are discussed in the later part of this paper.

\section{The exoskeletons for medical applications}

Exoskeleton for medical application are dedicated for two groups of users, the disable persons and elderly. According to [7], there are 15 million disabled persons with lower limb motor disorders. Moreover, just in USA, in each year almost 800000 brain strokes occur, and such patients critically need rehabilitation. The modern research on exoskeletons for medical application was started by M.Vukobratović [32] over 60 years ago. His team developed an active exoskeleton for rehabilitation of paraplegics. Till now, researchers had developed many active exoskeletons assisting patients in rehabilitation or supporting their walking $[2,9]$. The exoskeletons usually apply the electrical motors powering the ankle, knee and hip joints for assisting palsy or stroke patients in walking. The exoskeleton called Lokomat (launched 2016) [3] is used to rehabilitate the patients on a treadmill. It provides a stable walking pace and secures the body balance. Some studies are indicating that the exoskeletons supporting the body weight improve the speed of gait recovery after the brain stroke [1]. The aging population is a common global issue. Unfortunately, the muscle strength is weakening with the age, moreover in the old age the problems with keeping the postural balance are also appearing. There- fore, the exoskeletons as a daily support are needed. A Japanese company (CYBERDYNE) developed Hybrid Assistive Limb (HAL) which assist the wearer walking, standing up and sitting down [21, 22]. The works on HAL precursor started in 1997 and the first demonstration of HAL took place in 2012. Another example is Unplugged Powered Suit (UPS), a lightweight, highly flexible exoskeleton invented also in Japan [11] and launched in year 2015. UPS uses pump drives and a pneumatic gel muscle (PGM) for augmenting the user forces. This device is soft, lightweighted, it can be used for enhancing the strength of athletes and for rehabilitation as well. Our list of most relevant projects, closes the Brain-Controlled Adaptive Lower Limb Exoskeleton for rehabilitation of post-stroke paralyzed (BCLLE) [33] currently being under development within the Institute of Electrical and Electronics Engineers EPICS grant.

In the end of this part it should be emphasized that the needs of patients are very diverse, however, the common requirement are the robust, and reliable systems which is easy to wear.

\section{Actuation and motion generation: the main features}

\subsection{State of the art}

Exoskeleton are the wearable robots. They integrate sensors, mechanics and control systems. The basic control strategies are listed in Table 1 where the examples considered the medical, and military applications are summarized. The types of actuators and active joints are listed. The control system of exoskeleton BLEEX increases the closed loop system sensitivity to its user forces and torques without any direct measurement. In the position control mode, the information from several inclinometers was used for deciding about required joints position [35]. BLEEX has few sensors and is driven by hydraulic actuators powering the hip, knee and ankle joints. Differently than BLEEX, ONYX and exoskeleton X1 (2012-2017) dedicated for human assistance and space missions, are using many sensors which are mounted in the feet, knees and hips collecting the motion data which are used for predictive control. ONYX applies miniaturized electric actuators [13]. X1 utilize series elastic rotary actuators in hip and knee joints [30]. Electromyogram based (EMG based) control creates the human-machine interface where the exoskeleton works according to user's intention. EMG based control strategy was firstly used in HAL-3 (2000) and was farther refined in the HAL-5 version (2009). Most recent version of HAL exoskeleton has two modes of operation. In one mode, the device supports (stimulates by firm forcing) the predefined normal gait. When the patient wears HAL regularly, the gait pathologies are vanishing, and the gait is improving [6]. In the other mode of HAL operation, the EMG signals collected by surface electrodes are used as the templates for producing the gait support. The control system associates the EMG patterns with specific movements. Those patterns are used for producing the motor control commands $[28,21]$. Therefore, the system is capable to predict the next required position and drives accordingly the actuators $[34,36$, 6]. It is possible under the assumption that the user is able to produce clear (not blurred) EMG signals.

Electroencephalograms (EEG) are the signals providing the information about electrical activity of the brain. These electric signals are used for the motion control of paralyzed persons. The electrical activity of the brain is measured by small surface electrodes attached to scalp. In this case, the EEG signal patterns are associated with different movements. The patient needs an exercising for such type of control using the mind (the will) [27]. In 2005 the Media Lab's Biomechatronic Group from MIT delivered their first prototype with EEG controlled motion [18]. The project was farther developed. MIT exoskeleton applies 
Table 1. Lower limb exoskeletons: list of selected features

Tabela 1. Egzoszkielety kończyny dolnej: wykaz wybranych cech

\begin{tabular}{|c|c|c|c|c|c|c|}
\hline $\begin{array}{c}\text { Usage } \\
\text { categorization }\end{array}$ & Device name & $\begin{array}{l}\text { Starting year of } \\
\text { the project }\end{array}$ & Application & Control method & $\begin{array}{l}\text { Type of the } \\
\text { actuators }\end{array}$ & Active joints \\
\hline \multirow{3}{*}{$\begin{array}{r}\text { Military } \\
\text { application }\end{array}$} & BLEEX & 2000 & $\begin{array}{c}\text { Strength } \\
\text { augmentation } \\
\text { and movement } \\
\text { endurance }\end{array}$ & $\begin{array}{r}\text { Sensor-based } \\
\text { position/force/ } \\
\text { torque control }\end{array}$ & $\begin{array}{l}\text { Hydraulic } \\
\text { actuators }\end{array}$ & $\begin{array}{l}\text { Hip, knee, } \\
\text { ankle joints }\end{array}$ \\
\hline & ONYX & 2018 & $\begin{array}{c}\text { Increase } \\
\text { wearer's mobility } \\
\text { and reduce } \\
\text { fatigue }\end{array}$ & $\begin{array}{c}\text { Sensor-based } \\
\text { predictive control }\end{array}$ & $\begin{array}{l}\text { Electrical } \\
\text { actuators }\end{array}$ & Hip, knee \\
\hline & $\begin{array}{c}\text { MIT } \\
\text { Exoskeleton }\end{array}$ & 2005 & $\begin{array}{l}\text { Load-carrying } \\
\text { augmentation }\end{array}$ & $\begin{array}{l}\text { Quasi-passive } \\
\text { force/torque } \\
\text { control }\end{array}$ & $\begin{array}{c}\text { No active } \\
\text { actuators but } \\
\text { springs and } \\
\text { variable dampers }\end{array}$ & $\begin{array}{l}\text { Hip, knee, } \\
\text { ankle }\end{array}$ \\
\hline \multirow{3}{*}{$\begin{array}{r}\text { Medical } \\
\text { application }\end{array}$} & $\begin{array}{c}\text { Hybrid } \\
\text { Assistant limb } \\
\text { (HAL-3) }\end{array}$ & 2000 & $\begin{array}{l}\text { Assist disabled } \\
\text { and elder or } \\
\text { rehabilitation }\end{array}$ & $\begin{array}{l}\text { EMG sensor- } \\
\text { based predictive } \\
\text { control }\end{array}$ & $\begin{array}{l}\text { Electrical } \\
\text { motors }\end{array}$ & $\begin{array}{l}\text { Hip, knee, } \\
\text { ankle }\end{array}$ \\
\hline & $\mathrm{X} 1$ & 2012 & $\begin{array}{c}\text { Gait } \\
\text { rehabilitation, } \\
\text { and assisted } \\
\text { walking, } \\
\text { astronaut's } \\
\text { resistance training }\end{array}$ & $\begin{array}{c}\text { Sensor based } \\
\text { predictive control }\end{array}$ & $\begin{array}{c}\text { Series elastic } \\
\text { rotary actuators }\end{array}$ & Hip, knee \\
\hline & BCLLE & 2016 & $\begin{array}{l}\text { Rehabilitation } \\
\text { of post-stroke } \\
\text { paralyzed }\end{array}$ & $\begin{array}{c}\text { EEG based } \\
\text { predictive control }\end{array}$ & $\begin{array}{l}\text { High torque } \\
\text { electric motors }\end{array}$ & $\begin{array}{l}\text { Hip, knee, } \\
\text { ankle }\end{array}$ \\
\hline
\end{tabular}

quasi-passive control which means that no active actuators are used but springs at ankle and hip joints and a variable damper in the knee joints. The EEG-based control strategy is also applied in BCLLE [33] the exoskeleton which is currently under development, the motions are predicted using the gait patterns recovered from measured EMG or EEG signals.

The recent research on EEG based control [24, 31] delivers very promising results. However, such control method is still in the early stage of development and it strongly depends on sensing and sensor's quality.

Table 1 is giving the short overview of the properties of the most representative exoskeletons discussed in this paper.

\subsection{EMG signals analysis for EMG based control: research example}

It is obvious that the researchers designing the exoskeletons must be familiar with the human motion properties [5]. Such knowledge allows to design the joint motion ranges, to select the actuators and motion transmission systems and finally to design the control system such that it will support and not obstruct the intendent movements without forcing the wrong positions or the extreme motion speed. Accordingly, when developing the lower limbs exoskeletons, the knowledge of human gait features is necessary.

The leg motion during normal walking gait is divided to the swing and stance phase. The swing phase is the speed demanding, the leg-end moves along curve trajectory and it must be fast enough for avoiding obstacles and being placed on the ground according to the gait pattern. The supporting phase is torque demanding, the leg must absorb the landing impact and support the body weight. In the normal gait seven stages are distinguished, namely the 'heel strike', 'foot flat', 'mid stance', 'heel off', 'toe off', 'mid swing', 'heel strike'. The recognition of the gait stages basis on the measured EMG signals is needed for EMG based motion control as it was already mentioned. In our project, we investigated the muscles activity during normal slow walking of a female subject [34] considering barefoot, sneakers shoes and high heel footwear. The EMG signals were recorded for the main muscle groups of the lower limbs according to standards defined in gait monitoring systems.

The simple competitive network which not needs the training was clustering the pre-processed discretized EMG signals to the several groups (clusters). It was proved that those clusters are well associated with the gait stages. Fig. 3 is showing the EMG clustering results, in this case the left leg was considered, the gait phases together with visualization of leg position are also given. Showing the results for the left leg allows us to illustrate the stages shift between two legs in the normal, slow gait (note: in both Fig. 2 and 3 the drawings are starting from the double support phase however in the first case the leg goes next to the swing phase, while the left leg stays in support what is shown in Fig. 3). As it can be noticed (Fig. 3) the changes of classes occur mainly in the moments of change of the gait stages (indicated by vertical dotted line) or near to it. It confirms that clustering artificial network can be used for gait stages recognition. Considered gait is fundamental for the exoskeletons dedi- 


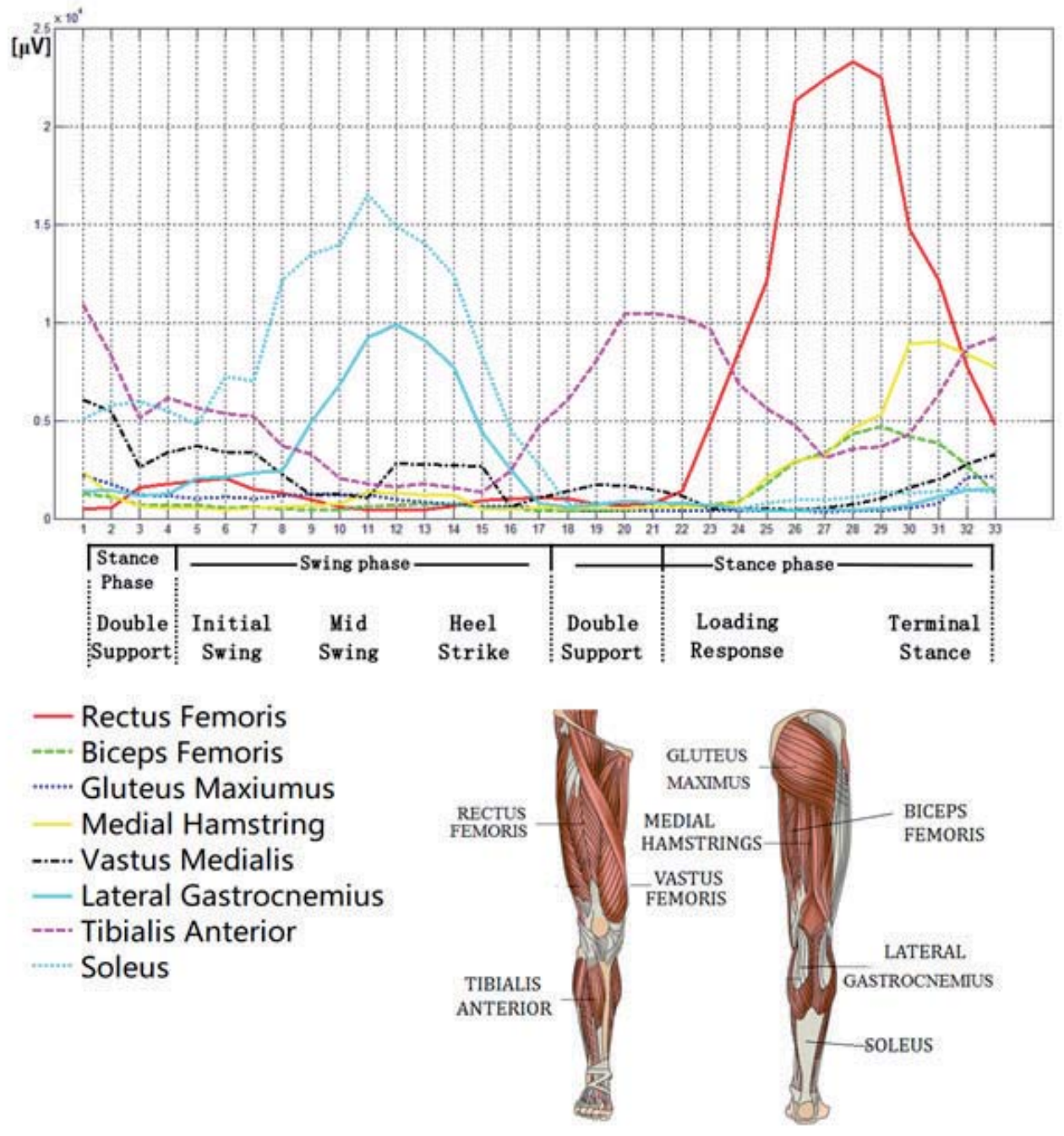

Fig. 2. Processed EMG signals for bare foot. The considered main muscle groups are pointed out

Rys. 2. Przetworzone sygnały EMG dla bosej stopy. Zaznaczono wzięte pod uwagę główne grupy mięśni

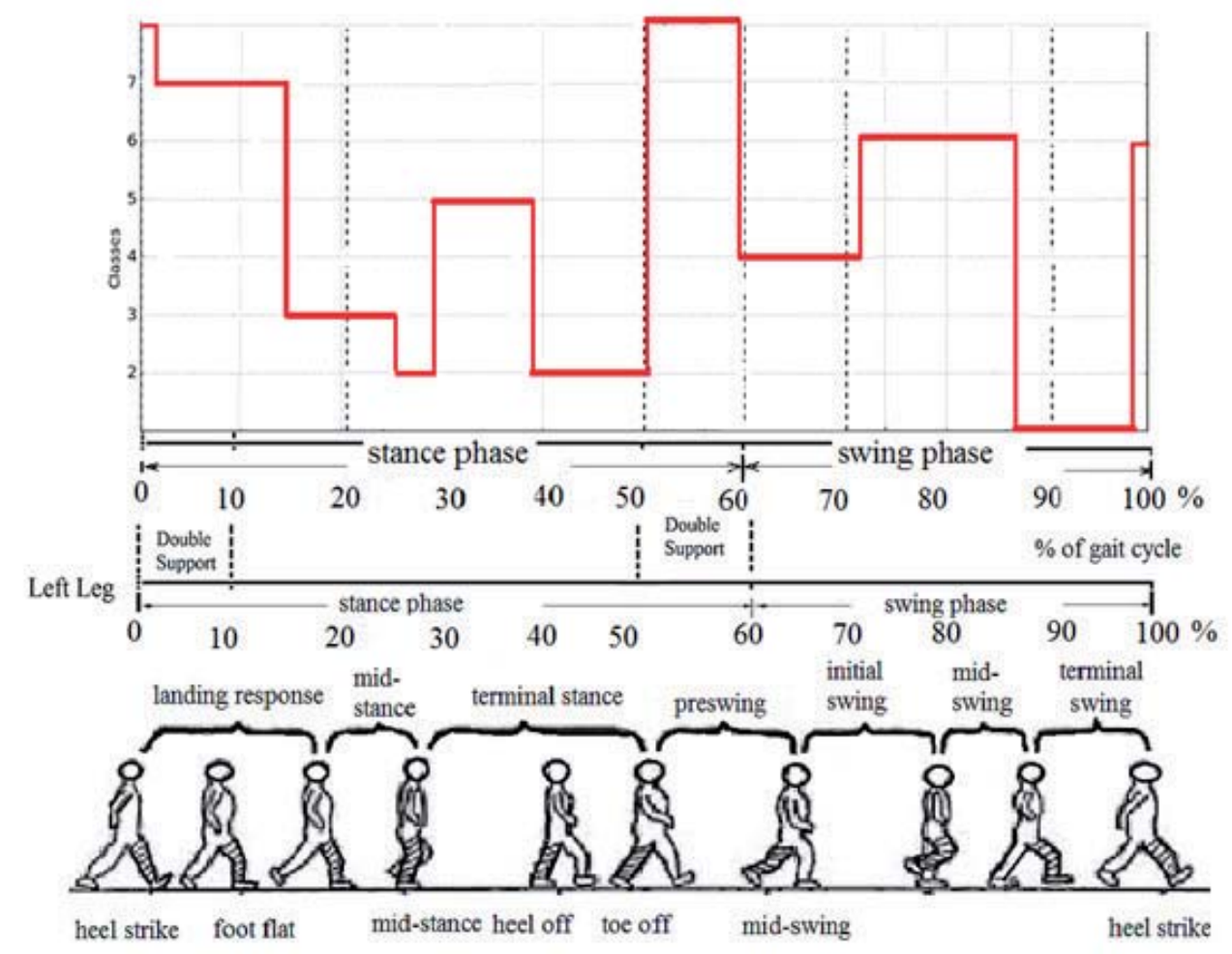

Fig. 3. The clustering results of the EMG signals. The data concern the left leg. The gait stages are also illustrated Rys. 3. Wyniki grupowania sygnałów EMG. Dane dotyczą lewej nogi. Zilustrowane są też etapy chodu 
cated to rehabilitation. Such gait is also used for detecting the motion impairments and the recovery processes. The details of the methods are given in [36].

\section{Conclusions}

Earlier exoskeletons for military applications, were using rather big hydraulic motors, with the progress in engineering, the electric motors become popular [15, 8]. The military users need light, endurable and flexible exoskeletons. ONYX is the example of such solution; this lower limb exoskeleton is easy to wear, and it is efficient in exploitation [13]. Meanwhile, due to the progress in power supply solutions the operation time is also improving. The challenge of exoskeletons for medical applications is to overcome the system complexity and the high cost. Differently than in the military application the users of medical exoskeletons are usually motion impaired and cannot voluntary produce their movements when keeping the stable posture. They need rigid and actuated assistance for supporting their body weight. Due to the development of efficient batteries, new flexible and light materials and progress in actuating techniques [29] the better solutions are now possible. Artificial muscles [4] are more often applied what allows to adjust the devices better to the human body structure and with reducing its weight. On the other hand, the progress in the sensing techniques and control methods is also very crucial. The refined EMG of EEG sensors provide reliable readings and sophisticated, artificial intelligence-based control algorithms, are associating the sensory data with the motion commands much better than it was years ago.

Meanwhile, the cost of exoskeleton is still very high and is over the acceptance level for majority of needing persons. For example, the retail price of HAL was approximately between $\$ 14,000$ and $\$ 19,000$ in 2011 , moreover the monthly rental fee was estimated to $\$ 1000$ [12].

It must be concluded that light, durable and not expensive lower limb exoskeletons is the most fundamental demand. In medical field they support rehabilitation, or they offer the walking possibility to the persons with motion disorders. In military or other special applications, they enhance the user's strength and motion efficiency.

\section{Acknowledgement}

The work on this paper was partially supported by National Natural Science foundation of China (No. 11702191), China Postdoctoral Science Foundation (No. 2018M631751). The research of EMG signals was performed at Warsaw University of Technology. The corresponding author is Linwei Lyu.

\section{References}

1. Ada L., Dean C.M., Vargas J, Ennis S., Mechanically Assisted Walking with Body Weight Support Results in More Independent Walking than Assisted Overground Walking in Non-Ambulatory Patients Early After Stroke: A Systematic Review, "Journal of Physiotherapy", Vol. 56, No. 3, 2010, 153-161, DOI: 10.1016/S1836-9553(10)70020-5.

2. Asbeck A., De Rossi S.M.M., Holt K.G., Walsh C.J., A Biologically Inspired Soft Exosuit for Walking Assistance, "The International Journal of Robotics Research", Vol. 34, No. 6, 2015, 744-762.

3. Barroso F., Santos C., Moreno J.C., Influence of the Robotic Exoskeleton Lokomat on the Control of Human Gait: An Electromyographic and Kinematic Analysis, IEEE $3^{\text {rd }}$ Portuguese Meeting in Bioengineering (ENBENG), Braga, 2013, DOI: 10.1109/ENBENG.2013.6518442.
4. Beyl P., Van Damme M., Van Ham R., Vanderborght B., Lefeber D., Pleated Pneumatic Artificial Muscle-Based Actuator System as a Torque Source for Compliant Lower Limb Exoskeletons, "IEEE/ASME Transactions on Mechatronics", Vol. 19, No. 3, 2014, 1046-1056, DOI: 10.1109/TMECH.2013.2268942.

5. Chen J., Mu X., Du F., Biomechanics Analysis of Human Lower Limb During Walking for Exoskeleton Design, "Journal of Vibroengineering", Vol. 19, No. 7, 2017, 5527-5539, DOI: $10.21595 /$ jve.2017.18459.

6. Dhindsa I.S., Agarwal R., Ryait H.S., A Novel Algorithm to Predict Knee Angle from EMG Signals for Controlling a Lower Limb Exoskeleton, CEUR Workshop Proceedings, 2016, 536-541, DOI: 10.18287/1613-0073-2016-1638-536-541.

7. Di Shi, Wuxiang Zhang, Wei Zhang, Xilun Ding, A Review on Lower Limb Rehabilitation Exoskeleton Robots, "Chinese Journal of Mechanical Engineering", Vol. 32, No. 74, 2019, DOI: 10.1186/s10033-019-0389-8.

8. Dollar A.M., Herr H., Lower Extremity Exoskeletons and Active Orthoses: Challenges and State-of-the-Art, "IEEE Transactions on Robotics", Vol. 24, No.1, 2008, 144-158, DOI: $10.1109 /$ TRO.2008.915453.

9. Gardner A.D., Potgieter J., Noble F.K., A Review of Commercially Available Exoskeletons' Capabilities, $24^{\text {th }}$ International Conference on Mechatronics and Machine Vision in Practice, 2017, DOI: 10.1109/M2VIP.2017.8211470.

10. Guizzo E., Goldstein H., The Rise of the Body Bots, "IEEE Spectrum", Vol. 42, No. 10, 2005.

11. https://exoskeletonreport.com/2015/12/unplugged-powered-suit/

12. https://www.lexology.com/library/detail.aspx?g=dbe03d2b-fad6-49d2-a72c-ed30845893ef.

13. https://www.lockheedmartin.com/en-us/products/exoskeleton-technologies/military.html

14. https://www.military.com/daily-news/2015/05/21/firmspitch-exoskeletons-and-body-armor-for-socoms-iron-mansuit.html

15. https://www.therobotreport.com/maxon-motor-exoskeleton-joint-actuator/

16. https://tech.slashdot.org/story/00/03/23/1011217/exoskeletons-for-human-performance-augmentation

17. https://spectrum.ieee.org/automaton/robotics/industrial-robots/sarcos-guardian-xo-powered-exoskeleton

18. https://www.media.mit.edu/groups/biomechatronics/overview/

19. http://www.freedigitalphotos.net/images/pill-bug-photo-p634175

20. https://www.flickr.com/photos/briangratwicke/17152476067/

21. Kawamoto H., Lee S., Kanbe S., Sankai,Y., Power Assist Method for HAL-3 Using EMG-Based Feedback Controller, IEEE International Conference on Systems, Man and Cybernetics, Vol. 2, 2003, 1648-1653.

22. Kawamoto H., Sankai Y., Power Assist System HAL-3 for Gait Disorder Person, International Conference on Computers for Handicapped Persons, Helping People Special Needs, Vol. 2398, 2002, 196-203.

23. Kazerooni H., The Berkeley Lower Extremity Exoskeleton, "Field and Service Robotics", Springer Tracts in Advanced Robotics, Vol. 25, 2006, 9-15,

DOI: $10.1007 / 978-3-540-33453-8-2$.

24. Lee K., Liu D., Perroud L., Chavarriaga R., Millánn J. R., A Brain-controlled Exoskeleton with Cascaded Event-Related Desynchronization Classifiers, Robotics and Autonomous Systems, Vol. 90, 2017, 15-23, DOI: $10.1016 /$ jarobot.2016.10.068.

25. Mosher R. S., Handyman to Hardiman, SAE Transactions, Vol. 76, 1968, 588-597, DOI: 10.4271/680088. 
26. Nicholas Y., Apparatus for Facilitating Walking, U.S. Patent $440.684,1890$.

27. Nicolelis M.A., Brain-machine Interfaces to Restore Motor Function and Probe Neural Circuits, Nature Reviews Neuroscience, Vol. 4, 2003, 417-422.

28. Ogata T., Abe H., Samura K., Hamada O., Nonaka M., Iwaasa M., Higashi T., Fukuda H., Shiota E., Tsuboi Y., Inoue, T. Hybrid Assistive Limb (HAL) Rehabilitation in Patients with Acute Hemorrhagic Stroke, Neurol Med Chir (Tokyo), Vol. 55, No. 12, 2015, 901-906.

29. Park S.J., Park C.H., Suit-type Wearable Robot Powered by Shape-memory-alloy-based Fabric Muscle. Scientific Reports, Vol. 9, No. 9157, 2019.

30. Rea R., Beck C., Rovekamp R., X1: A Robotic Exoskeleton for In-Space Countermeasures and Dynamometry, AIAA SPACE 2013 Conference and Exposition, 2013.

31. Tariq M., Trivailo P. M., Simic M., EEG-based BCI Control Schemes for Lower-Limb Assistive-Robots, Frontiers in Human Neuroscience, Vol. 12, 2018, 312-336.
32. Vukobratovic M., Hristic D., Stojiljkovic Z., Development of Active Anthropomorphic Exoskeletons, Medical and Biological Engineering, Vol. 12, No. 1, 1974, 66-80.

33. Vinoj P. G., Jacob S., Menon V. G., Rajesh S., Khosravi M. R., Brain-Controlled Adaptive Lower Limb Exoskeleton for Rehabilitation of Post-Stroke Paralyzed, IEEE Access 7, 2019, 132628-132648.

34. Wang J., Zielińska T., Gait Features Analysis Using Artificial Neural Networks - Testing the Footwear Effect, Acta of Bioengineering and Biomechanics, Vol. 19, No. 1, 2017, 17-32.

35. Yin Y., Human-Machine Force Interactive Interface and Exoskeleton Robot Techniques Based on Biomechanical Model of Skeletal Muscle, Biomechanical Principles on Force Generation and Control of Skeletal Muscle and their Applications in Robotic Exoskeleton, chapter 4, 2019, 117-134.

36. Zielińska T., Wang J., Two Methods of EMG Analysis for the Purpose of Exoskeletons and Robotic Rehabilitation Devices, ROMANSY 22 - Robot Design, Dynamics and Control, CISM International Centre for Mechanical Sciences, Vol. 584, 2018, 110-117.

\section{Badania nad egzoszkieletami zorientowane na wspomaganie czynności ruchowych}

\section{Streszczenie: W niniejszym artykule podsumowano wyniki badań przeprowadzonych nad egzoszkieletami przeznaczonymi do wspomagania czynności ruchowych. Przedstawiono ich główne cechy, a także główne podejścia ich sterowania. Podstawowymi obszarami użycia egzoszkieletów są zastosowania wojskowe i medyczne. Opisano zwięźle wyniki badań nad aktywacją mięśni podczas chodzenia przez człowieka. Obecne trendy rozwojowe przedstawiono w podsumowaniu.}

Słowa kluczowe: egzoszkielet kończyny dolnej, EMG, analiza chodu

\section{jikun Wang, PhD}

jikun.wang@pw.edu.pl

ORCID: 0000-0002-0201-2844

likun Wang received his MSc degree and PhD degree from Warsaw University of Technology, Faculty of Power and Aeronautical University, Poland. He employed by the Faculty of Mechatronics, Warsaw University of Technology as an assistant professor. He is the member of International Federation for the Promotion of Mechanism and Machine Science, TC for Robotics and Mecha-

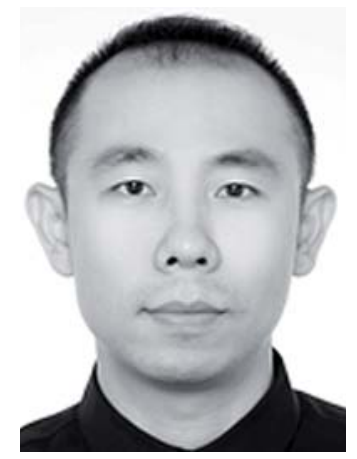
Linwei Lyu, PhD ORCID: 0000-0003-4874-7480

Linwei Lyu received his PhD degree from Faculty of mechanics, Jilin University, China. He employed by School of mechanical engineering, Tianjin University of Technology as a lecturer. His research interest was musculoskeletal system biomechanics..

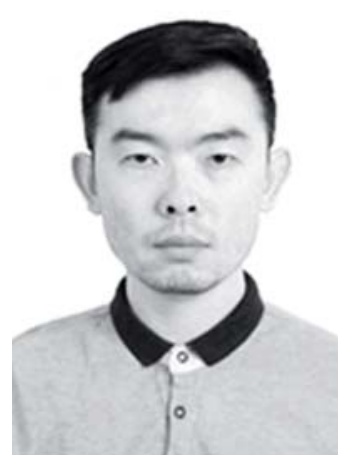

tronics since 2018. His research interest includes: biomechanics and robotics. 